\title{
TINJAUAN YURIDIS TERHADAP PUTUSAN HAKIM \\ DALAM TINDAK PIDANA PENODAAN AGAMA \\ (Studi Putusan Nomor 1537/Pid.B/2016/PN.Jkt.Utr)
}

\author{
Nuruz Zahroh Desy Syifaun Nida, Hidayatullah dan Henny Susilowati \\ Email : nuruzzahroh352@gmail.com, hidayatullah@umk.ac.id, \\ henny.susilowati@umk.ac.id \\ Fakultas Hukum Universitas Muria Kudus
}

\begin{abstract}
ABSTRAK
Penelitian berjudul Tinjauan Yuridis terhadap Putusan Hakim dalam Tindak Pidana Penodaan Agama (Studi Putusan Nomor 1537/Pid.B/2016/PN.Jkt.Utr) bertujuan mengetahui pembuktian serta pertimbangan hukum hakim dalam Putusan Nomor 1537/Pid.B/2016/PN.Jkt.Utr, sehingga digunakan metode pendekatan yuridis normatif dengan logika berpikir bersifat deduktif. Hasil pembahasan pertama, pembuktian pada penelitian ini diperoleh melalui alat bukti keterangan saksi, keterangan ahli, surat dan keterangan terdakwa. Pada pembuktian ini lebih ditekankan pada alat bukti keterangan ahli yang digolongkan dalam ahli bahasa, agama dan hukum pidana. Kedua, hakim menyatakan perbuatan terdakwa telah memenuhi unsur-unsur dalam Pasal 156a huruf a KUHP, sehingga disampaikan hakim menggunakan interpretasi multidisipliner. Merujuk pembahasan kepada tim penyusun RUU KUHP untuk memasukkan pengaturan kriteria khusus penodaan agama dalam ius constituendum.
\end{abstract}

Kata Kunci: Penodaan Agama, Pembuktian, Alat Bukti 


\section{PENDAHULUAN}

Bangsa Indonesia merupakan bangsa yang majemuk, yang terdiri dari berbagai macam suku, ras, budaya, bahasa, adat istiadat dan agama. Salah satu bentuk keanekaragaman bangsa Indonesia ialah adanya pengakuan lebih dari satu agama di Indonesia. Sebagai jaminan kebebasan beragama di negara ini, Undang-Undang Dasar Negara Republik Indonesia Tahun`1945 yang selanjutnya ditulis UUD NRI Tahun 1945 telah menjaminnya dalam Pasal 28E ayat (1) dan (2). Kebebasan beragama sebagai non derogahble rights yang tidak boleh mendapat perlakuan diskriminatif. Terjaminnya kebebasan beragama tidak hanya dijamin dalam UUD NRI Tahun 1945, hal tersebut juga terjamin dalam Pasal 22 Undang-Undang Nomor 39 Tahun 1999 tentang Hak Asasi Manusia. Secara internasional kebebasan beragama dijamin dalam International Convenant on Civil and Political Rights (Konvenan Internasional tentang HakHak Sispil dan Politik). Kemudian tepat pada tanggal 28 Oktober 2005 Indonesia meratifikasinya melalui Undang-Undang Nomor 12 Tahun 2005 tentang Pengesahan International Convenant on Civil ad Political Rights (Konvenan Internasional tentang HakHak Sispil dan Politik). Pelaksanaan kebebasan beragama bukan berarti melupakan hak-hak orang lain, sehingga kebebasan setiap orang dibatasi dengan hak orang lain. Sebagaimana telah diatur dalam Pasal 28J UUD NRI Tahun 1945 diantaranya yaitu menghormati hak asasi orang lain termasuk dalam kebebasan beragama.

Penodaan agama merupakan suatu perbuatan yang mengganggu dalam kehidupan berbangsa. Sebagaimana telah diketahui bersama bahwa Indonesia telah mengakui enam agama yaitu Islam, Kristen, Hindu, Budha, Katholik dan Khonghucu sebagaimana diatur dalam Penjelasan UndangUndang Nomor 1/PNPS/1965 tentang Pencegahan Penyalahgunaan dan Penodaan Agama. Hal tersebut sebagai upaya pemerintah untuk memelihara hubungan dalam kehidupan berbangsa dan bernegara. Berdasarkan Riset SETARA Institute sejak tahun 1965 sampai dengan tahun 2017 telah terjadi 97 kasus Penodaan Agama di Indonesia. ${ }^{14}$ Kasus terakhir yaitu Basuki Tjahaja Purnama alias Ahok (2017) yang menyisipkan Surat Al Maidah ayat 51 pada saat menyampaikan pidato di Kepulauan Seribu.

Kesemua kasus-kasus tersebut tidak terlepas dari jeratan hukum positif Indonesia. Putusan-putusan atas kasus penodaan agama yang terjadi di Indonesia mendatangkan pemikiran pro kontra baik dikalangan akademisi, politisi dan masyarakat. Hal ini juga berlaku terhadap putusan Nomor 1537/Pid.B/2016/PN.Jkt.Utr yang menyatakan bahwa Basuki Tjahaja Purnama alias Ahok telah melakukan tindak pidana penodaan agama. Kalangan pro menyatakan bahwa Basuki Tjahaja Purnama telah melakukan penodaan agama, dengan alasan bahwa pidato Basuki Tjahaja Purnama di Kepulauan Seribu yang menyisipkan surat Al-Maidah ayat 51 merupakan bagian dari Al-Qur'an. Atas pidato yang disampaikan Basuki Tjahaja Purnama alias Ahok

\footnotetext{
${ }^{14}$ Estu Suryowati, "SETARA Institute: Kasus Penodaan Agama Menguat Pasca Reformasi”, http://nasional.kompas.com/ read/2017/05/24/ $\underline{16354351 / \text { setara.institute.kasus.penodaan.aga }}$ ma.menguat.pasca.reformasi, diakses pada tanggal 2 Desember 2017 pukul 10.57 WIB.
} 
menimbulkan keresahan di masyarakat khususnya bagi umat muslim di Indonesia.

Disisi lain, kalangan kontra menyatakan bahwa Basuki Tjahaja Purnama alias Ahok tidak melakukan penodaan agama dengan alasan bahwa pidato yang disampaikan hanya menyinggung para politisi yang berlindung dibalik surat Al-Maidah tersebut.

Pada penelitian sebelumnya yang mengkaji Putusan Nomor 1537/Pid.B/2016/PN.Jkt.Utr terkait penerapan pasal 156a KUHP, serta penodaan agama dalam perspektif Hukum Islam. Pada penelitian ini, Penulis mengkaji terkait pembuktian unsur-unsur penodaan agama serta pertimbangan hukum hakim yang menjatuhkan terdakwa melakukan tindak pidana penodaan agama. Berdasarkan uraian latar belakang di atas, penulis tertarik menulis judul penelitian "Tinjauan Yuridis terhadap Putusan Hakim dalam Tindak Pidana Penodaan Agama (Studi Putusan Nomor 1537/Pid.B/2016/PN.Jkt.Utr)"

Berdasarkan uraian latar belakang tersebut, maka perumusan masalah dalam penulisan ini adalah sebagai berikut:

1. Bagaimana pembuktian unsur penodaan agama dalam proses peradilan pada kasus tindak pidana penodaan agama (Studi Putusan Nomor

1537/Pid.B/2016/PN.Jkt.Utr)?

2. Bagaimana pertimbangan hukum hakim atas alat-alat bukti yang terungkap dalam proses peradilan kasus tindak pidana penodaan agama (Studi Putusan Nomor 1537/Pid.B/2016/PN.Jkt.Utr)?

\section{METODE PENELITIAN}

Nilai ilmiah suatu pembahasan dan pemecahan masalah terhadap legal issue yang diteliti sangat tergantung kepada cara pendekatan (approach) yang digunakan. Jika pendekatan yang digunakan tidak tepat, maka bobot pelitian dianggap tidak akurat. Pada penelitian ini menggunakan pendekatan kasus (case approach). Adapun penjelasan dari pendekatan kasus (case approach) pada penelitian ini adalah pendekatan yang bertujuan untuk mempelajari norma-norma atau kaidah hukum yang dilakukan dalam praktik hukum. Terutama mengenai kasus yang telah diputus yang menjadi fokus penelitian. $^{15}$

Konsekuensi pemilihan topik permasalahan yang dikaji pada penelitian yang objeknya adalah permasalahan hukum, maka tipe penelitian yang digunakan adalah penelitian yuridis normatif, yakni penelitian yang difokuskan mengkaji penerapan norma-norma dalam hukum positif. ${ }^{16}$ Proses berpikir secara deduktif merupakan berpikir dari hal umum menuju yang khusus. Pada penelitian ini penulis menggunakan proses berpikir secara deduktif dimana beranjak dari hal yang umum yaitu unsur-unsur dalam Pasal 156a huruf a KUHP ke hal yang bersifat khusus yaitu Putusan Nomor 1537/Pid.B/2016/PN.Jkt.Utr.

\section{HASIL PENELITIAN DAN PEMBAHASAN}

1. Pembuktian Unsur Penodaan Agama dalam Proses Peradilan Pada Kasus Tindak Pidana

\footnotetext{
${ }^{15}$ Johny Ibrahim, "Teori dan Metodologi Penelitian Hukum Normatif", Bayumedia Publishing, Malang, 2007, hlm. 321

${ }^{16}$ Ibid., hlm. 295.
} 
Penodaan Agama (Studi Putusan Nomor 1537/Pid.B/2016

\section{/PN.Jkt.Utr)}

a) Kasus Posisi

Peristiwa ini diawali pada hari Selasa tanggal 27 September 2016 sekitar pukul 08.30-10.30 WIB, Basuki Tjahaja Purnama alias Ahok yang pada saat itu berkedudukan sebagai Gubernur DKI Jakarta melaksanakan kunjungan kerja di Tempat Pelelangan Ikan (TPI) Kelurahan Pulau Panggang, Kecamatan Pulau Seribu Selatan, Kabupaten Administrasi Kepulauan Seribu, Provinsi DKI Jakarta. Kunjungan kerja tersebut merupakan kunjungan kerja dalam rangka panen budidaya ikan kerapu, yang dihadiri oleh para pejabat dan nelayan setempat. Pada kunjungan kerja tersebut Gubernur DKI Jakarta juga menyampaikan pidato terkait dengan kunjungan kerja.

Pada waktu tersebut tim humas dalam hal ini Diskominfomas Provinsi DKI Jakarta juga melakukan rekaman video rangkaian kunjungan kerja yang pada hari selanjutnya diunggah pada akun youtube Pemprov DKI Jakarta dengan durasi video 1 jam 48 menit. Namun pada tanggal 6 Oktober 2016 seseorang yang bernama Buni Yani menggunggah penggalan video kunjungan kerja Basuki Tjahaja Purnama dengan memberikan transkrip pada unggahannya, akan tetapi terdapat satu kata yang tidak dimasukkan Buni Yani dalam transkrip yang diunggah, yaitu tidak adanya kata pakai.

Sejak beredarnya video tersebut banyak laporan yang masuk di Kantor Kepolisian bahwa Basuki Tjahaja Purnama alias Ahok telah melakukan penistaan terhadap agama. Adapun penggalan isi pidatonya ialah sebagai berikut: "..jadi saya ingin cerita ini supaya bapak ibu semangat, jadi gak usah pikiran ah nanti kalau gak ke pilih, pasti Ahok programnya bubar, engga saya sampai Oktober 2017, jadi jangan percaya sama orang, kan bisa aja dalam hati kecil bapak ibu ga pilih saya, ya kan dibohongi pakai surat Al Maidah ayat 51 macem-macem itu, itu hak bapak ibu, yah, jadi kalau bapak ibu perasaan gak bisa pilih nih karena saya takut masuk neraka dibodohin gitu ya, nggak papa, karna inikan panggilan bapak ibu. Program ini jalan saja, jadi bapak ibu nggak usah merasa gak enak, dalam nuraninya ga bisa milih Ahok, gak suka sama Ahok nih, tapi programnya gua kalo trima ngga enak dong jadi utang budi jadi jangan bapak ibu punya perasaan nggak enak nanti mati pelanpelan loh kena stroke."

Kalimat yang bercetak miring di atas merupakan kalimat yang dijadikan dasar para pelapor untuk melaporkan Basuki Tjahaja Purnama melakukan penistaan agama. Sehubungan dengan adanya peristiwa tersebut Majelis Ulama Indonesia DKI Jakarta mengeluarkan surat teguran yang intinya dilarang melakukan perbuatan yang meresahkan masyarakat. Hari selanjutnya tepatnya 10 Oktober 2016, Basuki Tjahaja Purnama memohon maaf kepada seluruh umat muslim yang merasa tersinggung atas isi pidato yang disampaikan pada kunjungan kerja di Kepulauan Seribu. Hari selanjutnya, 11 Oktober 2016 Majelis Ulama Indonesia (MUI) mengeluarkan Pendapat dan Sikap Keagamaan Majelis Ulama Indonesia Nomor Kep-9811/MUI/X/2016 yang pada intinya Majelis Ulama Indonesia menyatakan bahwa perkataan atau penggalan isi pidato kunjungan kerja di atas 
merupakan menghina Al Qur'an dan menghina ulama.

b) Analisis terhadap Pembuktian Unsur Penodaan Agama dalam Proses Peradilan Pada Kasus Tindak Pidana Penodaan Agama (Studi Putusan Nomor 1537/Pid.B/2016/PN.Jkt.Utr)

1) Alat Bukti

(a) Keterangan Saksi

Sebagaimana telah tercantum dalam Pasal 1 angka 27 KUHAP, bahwa:

"Keterangan saksi adalah salah satu alat bukti dalam perkara pidana yang berupa keterangan dari saksi mengenai suatu peristiwa pidana yang ia dengar, ia lihat sendiri dan ia alami sendiri dengan menyebut alasan dari pengetahuannya."

Hal tersebut mengartikan bahwa keterangan saksi yang dapat dijadikan alat bukti ialah keterangan dari saksi dalam suatu peristiwa pidana yang mana saksi tersebut mendengar, melihat dan mengalami sendiri. Pada perkembangannya definisi keterangan saksi diperluas, hal tersebut berdasarkan Putusan Mahkamah Konstitusi Nomor 65/PUU-VIII/2010 tertanggal 8 Agustus 2011. Berdasarkan Putusan Nomor 1537/Pid.B/2016/PN.Jkt.Utr, maka dapat disampaikan:

a) Saksi-saksi yang tercantum dalam putusan tersebut tidak semuanya hadir, terdapat saksi tidak dapat hadir di persidangan dikarenakan telah meninggal dunia. Sehingga keterangan saksi di dalam Berita Aacara Pemeriksaan (BAP) dibacakan di persidangan.

b) Terpenuhinya asas unus testis nullus testis, hal ini dikarenakan saksi-saksi yang dihadirkan memenuhi minimal. Pada kasus tersebut terdapat 25 saksi yang mana penulis cermati dalam putusan terdapat korelasi antara saksi yang satu dengan saksi yang lain sehingga saksi tidak berdiri sendiri.

c) Keterangan saksi yang dijadikan alat bukti tidak harus saksi yang pada saat peristiwa terjadi mendengar, melihat dan mengalami. Sebagaimana telah disampaikan bahwa terdapat Putusan Mahkamah Konstitusi Nomor 65/PUU-VIII/2010 yang memperluas definisi sebagai alat bukti.

(b) Keterangan Ahli

Pengaturan keterangan ahli sebagai alat bukti merupakan hal yang baru di dalam KUHAP, hal tersebut dikarenakan di dalam HIR tidak mencantumkannya. ${ }^{17}$ Pasal 1 angka 28 KUHAP menyatakan bahwa:

"Keterangan ahli adalah keterangan yang diberikan oleh seorang yang memiliki keahlian khusus tentang hal yang diperlukan untuk membuat terang suatu perkara pidana guna kepentingan pemeriksaan."

Berdasarkan definisi tersebut maka, ahli yang dihadirkan harus sesuai dengan pokok perkara. Merujuk pada ketentuan yang tercantum dalam KUHAP, keahlian yang disampaikan pada keterangan ahli didasarkan pada pengetahuan dan pengalaman yang dimiliki, tidak didasarkan pada pendidikan formal. KUHAP tidak memberikan batasan kriteria seorang ahli memenuhi jenjang pendidikan tertentu. Terdapat perbedaan antara keterangan ahli yang disampaikan di

\footnotetext{
${ }^{17}$ Suryono Sutarto, "Hukum Acara Pidana Jilid II", Badan Penerbit Fakultas Hukum Universitas Muria Kudus, Kudus, 1999, hlm. 48.
} 
persidangan dengan keterangan ahli secara tertulis yang disampaikan di persidangan. Apabila seorang ahli menyampaikan keterangan di bawah sumpah serta disampaikan secara langsung di persidangan, maka keterangan tersebut dapat dijadikan sebagai alat bukti keterangan ahli yang sah. Sementara keterangan ahli yang dibawah sumpah serta secara tertulis disampaikan di luar pengadilan atau dibacakan di sidang pengadilan merupakan alat bukti surat dan alat bukti keterangan ahli. ${ }^{18}$ Pada penelitian ini, terkait dengan pembuktian unsur penodaan agama ahli yang dibutuhkan ialah ahli bahasa, ahli agama serta ahli hukum pidana. Pada Putusan Nomor 1537/Pid.B/2016/PN.Jkt.Utr ahli yang dihadirkan meliputi:

(1) Keterangan Ahli Bahasa

Pada pembuktian penodaan agama ini dibutuhkannya ahli bahasa dikarenakan untuk memberikan definisi terkait kata penodaan. Berdasarkan keterangan-keterangan ahli bahasa di atas dapat disampaikan, bahwa adanya perbedaan pendapat terkait dengan definisi penodaan. Ahli bahasa Prof. Mahyuni, M.A. Ph.D. menyatakan bahwa penodaan memiliki arti menodai atau mencederai sedangkan menurut ahli bahasa Dr. Rahayu Sutiarti bahwa penodaan berasal dari kata dasar noda yang memiliki arti menjelekkan. Sedangkan ahli bahasa Prof. Herminigildus Bambang Kaswanti Purwo tidak memberikan definisi terkait dengan penodaan, ahli menyatakan bahwa pokok dari isi pidato tersebut merupakan pemerintah daerah provinsi DKI Jakarta yang memiliki program di

\footnotetext{
${ }^{18}$ Eddy O.S. Hiariej, "Teori dan Hukum Pembuktian”, Erlangga, Jakarta, 2012, hlm. 107.
}

Kepulauan Seribu yaitu budidaya ikan kerapu. Perbedaan pendapat terkait definisi penodaan agama mendatangkan pandangan pro dan kontra. Oleh karena ini akan lebih baik apabila terdapat definisi khusus tentang penodaan agama. Menurut Penulis berdasarkan Kamus Besar Bahasa Indonesia penodaan berdiri dari kata dasar noda yang memiliki arti menyebabkan bercak, sedangkan menodai menjadikan adanya noda, menjelekkan. Dikaitkan dengan pidato yang disampaikan bahwasanya tidak terdapat upaya untuk menodai yang dalam hal ini menodai agama islam. Penulis juga berpendapat dalam memaknai suatu teks perlu dibaca isi keseluruhan teks, bukan hanya penggalannya saja. Sehingga yang disampaikan dalam pidato tersebut merupakan tentang budidaya ikan kerapu, namun diselingi dengan cerita atau pengalaman yang pernah dialami Basuki Tjahaja Purnama tekait dengan pencalonan menjadi kepala daerah.

(2) Keterangan Ahli Agama

Berdasarkan keterangan-ketarangan ahli agama yang telah disampaikan, kata auliya' memiliki banyak makna diantara pemimpin, pelindung, teman setia, penolong, teman dekat. Perbedaan makna tersebut dikarenakan metode yang digunakan dalam menafsirkan berbeda-beda, serta pengacuan terhadap ashbabun nuzul atau sebab-sebab diturunkannya Al Qur'an dalam hal ini Surat Al Maidah ayat 51 yang juga berbeda. Terkait terjemahan auliya' yang berbeda-beda penulis mengacu pada terjemahan yang dikeluarkan oleh Kementerian Agama yang memiliki makna teman dekat. Hal ini dikarenakan bahwa Kementerian Agama merupakan lembaga negara yang memiliki kewenangan dibidang agama yang dianut di Indonesia, terkhusus dalam hal 
terjemahan Al Qur'an yang merupakan kitab suci umat islam.

\section{(3) Keterangan Ahli Hukum Pidana}

Berdasarkan keterangan-keterangan ahli yang telah disampaikan pada putusan bahwa pasal yang mengatur terkait penodaan agama ialah Pasal 156a huruf a KUHP, yang mana pasal tersebut merupakan pasal sisipan melalui Pasal 4 Undang-Undang Nomor 1/PNPS/1965 tentang Pencegahan dan/atau Penodaan Agama. Adapun bunyi pasal tersebut ialah:

"Dipidana dengan pidana penjara selama-lamanya lima tahun barangsiapa dengan sengaja di muka umum mengeluarkan perasaan atau melakukan perbuatan:

a. Yang pada pokoknya bersifat prmusuhan, penyalahgunaan atau penodaan terhadap suatu agama yang dianut di Indonesia;

b. Dengan maksud agar siapay orang tidak menganut agama apapun juga, yang bersandikan ke-Tuhanan Yang Maha Esa."

Berdasarkan pasal tersebut, maka unsurunsur Pasal 156a huruf a KUHP ialah: barang siapa, dengan sengaja, di muka umum mengeluarkan atau melakukan perbuatan yang pada pokoknya bersifat permusuhan, penyalahgunaan atau penodaan terhadap suatu agama yang dianut di Indonesia. Adapun penjelasannya ialah:

1. Barang siapa

Unsur barang siapa merupakan unsur yang merujuk pada subjek hukum. Adapun subjek hukum terdiri dari orang dan badan hukum. Pada kasus ini sesuai dengan dakwaan dari jaksa penuntut umum, bahwa subjek hukum yang dimaksud dalam hal ini adalah Basuki Tjahaja Purnama.

2. Dengan sengaja
Dipidananya seseorang tidaklah cukup apabila orang tersebut telah melakukan suatu perbuatan yang bertentangan dengan hukum. Meskipun perbuatan telah memenuhi rumusan delik dalam undang-undang, namun hal tersebut belum memenuhi syarat untuk orang tersebut melakukan tindak pidana. Syarat yang harus dipenuhi adalah orang yang melakukan perbuatan harus memiliki kesalahan, hal ini dikarenakan berlakunya asas tiada pidana tanpa kesalahan. Kesalahan dalam arti luas yaitu pertanggungjawaban dalam hukum pidana yang di dalamnya terkandung makna dapat dicelanya si pembuat. ${ }^{19}$ Bentuk dari kesalahan ialah kesengajaan (dolus) dan kealpaan (culpa). Kesengajaan menurut Memori van Toelichting ialah menghendaki dan mengetahui (willen en wetens), hal ini berarti bahwa seseorang melakukan suatu tindakan sengaja harus menghendaki dan menginsyafi perbuatan dan akibatnya. Sedangkan kealpaan (culpa) menurut Memori van Toelichting kealpaan di satu pihak berlawanan dengan kesengajaan dan dipihak lain dengan hal yang kebetulan (toevel atau casus). Pada penelitian ini bentuk kesalahan yang digunakan ialah kesengajaan, hal tersebut dibuktikan adanya kata dengan sengaja pada rumusan Pasal 156a huruf a KUHP. Terkait dengan kesengajaan, hukum pidana membaginya dalam dua (2) teori yaitu: ${ }^{20}$

\footnotetext{
${ }^{19}$ Sudarto, “Hukum Pidana I", Yayasan Sudarto Fakultas Hukum Universitas Diponegoro, Semarang, 1990, hlm. 90.

${ }^{20}$ Ibid., hlm. 102.
} 
a. Teori kehendak

Bahwa kesengajaan diartikan sebagai kehendak untuk mewujudkan unsur-unsur delik dalam rumusan undang-undang.

b. Teori pengetahuan atau membayangkan

Sengaja berarti membayangkan akan timbulnya akibat perbuatannya orang tak bisa menghendaki akibat, melainkan hanya membayangkan akibat yang timbul.

3. Di muka umum Mengeluarkan atau melakukan perbuatan yang pada pokoknya bersifat permusuhan, penyalahgunaan atau penodaan terhadap suatu agama yang dianut di Indonesia

(c) Surat

Surat menjadi salah satu alat bukti dalam perkara pidana. Hal tersebut telah diatur dalam Pasal 187 KUHAP yang menyatakan bahwa surat dapat dijadikan alat bukti apabila surat tersebut dibuat atas sumpah jabatan atau dikuatkan dengan sumpah. Pada Pasal 187 KUHAP ini merinci beberapa surat yang dimaksud sebagai alat bukti dalam perkara pidana Terdapat ahli yang tidak dapat menyampaikan keterangannya di dalam persidangan, namun hal tersebut tetap menjadi alat bukti yang salah satunya ialah alat bukti surat. Sehingga dapat disampaikan bahwa pada pembuktian tindak pidana penodaan agama Putusan Nomor 1537/Pid.B/2016/PN.Jkt.Utr ini terdapat alat bukti surat.

(d) Petunjuk

Berdasarkan Pasal 188 ayat (1) KUHAP, petunjuk merupakan suatu perbuatan, kejadian atau keadaan, yang karena persesuainnya, baik antara yang satu dengan yang lain, maupun dengan tindak pidana itu sendiri, menandakan bahwa telah terjadi suatu tindak pidana dan siapa pelakunya. Pada proses pembuktian, alat bukti petunjuk dapat diperoleh dari keterangan saksi, surat, dan keterangan terdakwa. Pada konteks teori pembuktian, petunjuk ialah bukti tidak langsung yang bersifat sebagai pelengkap atau accecories evidence. ${ }^{21}$ Sehingga berdasarkan keterangan saksi, surat dan keterangan terdakwa yang telah disampaikan dapat diperoleh alat bukti petunjuk. Namun, penentuan ada atau tidaknya alat bukti petunjuk hanya dapat dilakukan oleh hakim.

(e) Keterangan Terdakwa

Keterangan terdakwa merupakan salah satu alat bukti dalam pembuktian tindak tindak pidana. Sebagaimana telah disampaikan dalam Pasal 189 KUHAP, bahwa:

(1) Keterangan terdakwa ialah apa yang terdakwa nyatakan di sidang tentang perbuatan yang ia lakukan atau yang ia ketahui sendiri atau alami sendiri.

(2) Keterangan terdakwa yang diberikan di luar sidang dapat digunakan untuk membantu menemukan bukti di sidang, asalkan keterangan itu didukung oleh suatu alat bukti yang sah sepanjang mengenai hal yang didakwakan kepadanya.

(3) Keterangan terdakwa hanya dapat digunakan terhadap dirinya sendiri.

(4) Keterangan terdakwa saja tidak cukup untuk membuktikan bahwa ia bersalah melakukan perbuatan yang didakwakan kepadanya, melainkan harus disertai dengan alat bukti yang lain.

2) Barang Bukti

Berbicara terkait dengan alat bukti, tentu berkaitan erat dengan barang

\footnotetext{
${ }^{21}$ Eddy O.S. Hiariej, Op.Cit., hlm. 112.
} 
bukti. Tidak terdapat definisi khusus tentang barang bukti, secara umum barang bukti merupakan benda-benda yang disita berdasarkan Pasal 39 KUHAP yang fungsinya disejajarkan dengan sarana-sarana pembuktian menurut Pasal 184 ayat (1) dan (2) KUHAP. ${ }^{22}$ Pada Kitab Undang-Undang Hukum Acara Pidana tidak mengatur secara jelas tentang barang bukti, namun di dalam Pasal 39 ayat (1) KUHAP menyatakan tentang bendabenda yang dapat disita. Adapun bunyi pasal tersebut adalah:

(1) Yang dapat dikenakan penyitaan adalah:

a. Benda atau tagihan tersangka atau terdakwa yang seluruh atau sebagian diduga diperoleh dari tindakan pidana atau sebagai hasil dari tindak pidana;

b. Benda yang telah dipergunakan secara langsung untuk melakukan tindak pidana atau untuk mempersiapkannya;

c. Benda yang dipergunakan untuk menghalang-halangi penyelidikan tindak pidana;

d. Benda yang khusus dibuat atau diperuntukkan melakukan tindak pidana;

e. Benda yang lain mempunyai hubungan langsung dengan tindak pidana.

Pada kasus ini barang bukti yang disita antara lain:

a) Flashdisk berisi video kunjungan kerja Basuki Tjahaja Purnama tertanggal 27 September 2016.

b) Flashdisk berisi video wawancara dengan Basuki Tjahaja Purnama di

22 Ratna Nurul Afifah, "Barang Bukti dalam Proses Pidana”, Sinar Grafika, Jakarta, 1998, hlm. 71.
Balakota Jakarta tertanggal 7 Oktober 2016.

c) Flashdisk berisi e-book "Merubah Indonesia" yang ditulis oleh Basuki Tjahaja Purnama.

Adapun benda-benda yang dapat disita menurut Hari Sasangka dapat digolongkan sebagai berikut: ${ }^{23}$

1) Corpora Delicti

a. Barang-barang yang menjadi objek tindak pidana.

b. Barang-barang yang dibuat atau dihasilkan dari tindak pidana.

c. Barang-barang yang pada umumnya dapat dijadikan bukti untuk memberatkan tindak pidana seseorang.

2) Instrumen Delicti

Merupakan barang yang dijadikan alat untuk melakukan suatu tindak pidana.

3) Sistem Pembuktian

Berdasarkan teori sistem pembuktian, KUHAP menganut sistem pembuktian menurut undang-undang secara negatif. Sistem pembuktian menurut undang-undang secara negatif merupakan sistem pembuktian gabungan antara sistem pembuktian menurut undang-undang positif dengan sistem pembuktian conviction-in time. Berdasarkan hal tersebut maka menurut sistem ini salah atau tidaknya terdakwa didasarkan pada alat-alat bukti dan keyakinan hakim. Seagaimana yang telah diuraikan di atas bahwa alat-alat bukti yang muncul di persidangan diantaranya ialah keterangan saksi, keterangan ahli serta keterangan terdakwa. Barang bukti dalam hal ini berkedudukan sebagai alat yang

\footnotetext{
23 Hari Sasangka, "Penyidikan, Penahanan, Penuntutan dan Praperadilan dalam Teori dan Praktuk”, Mandar Maju, Bandung, 2007, hlm. 65 .
} 
memperkuat alat-alat bukti yang ada selama di persidangan.

\section{Pertimbangan Hukum Hakim} atas Alat-Alat Bukti yang Terungkap dalam Proses Peradilan Tindak Pidana Penodaan Agama (Studi Putusan No. 1537/Pid.B/ 2016/PN.Jkt.Ut)

Pada Putusan Nomor 1537/Pid.B /2016/PN.Jkt.Utr pertimbanganpertimbangan hakim yang menyatakan bahwa terdakwa telah melakukan tindak pidana penodaan agama ialah:

Adapun pertimbangan hukum hakim atas alat-alat bukti yang terungkap dalam proses peradilan kasus tindak pidana penodaan agama pada Putusan Nomor 1537/Pid.B/2016 /PN.Jkt.Utr ialah berdasarkan dakwaan alternatif oleh Penuntut Umum, pengadilan menyatakan terpenuhinya dakwaan alternatif pertama yaitu Pasal 156a huruf a KUHP yang rumusannya sebagai berikut "dipidana dengan pidana penjara selama-lamanya lima tahun barang siapa dengan sengaja di muka umum mengeluarkan perasaan atau melakukan perbuatan yang pada pokoknya bersifat permusuhan, penyalahgunaan atau penodaan terhadap suatu agam yang dianut di Indonesia". Rumusan pasal tersebut terdiri beberapa unsur diantaranya pertama barang siapa, kedua dengan sengaja, ketiga dimuka umum mengeluarkan perasaan atau melakukan perbuatan yang pada pokoknya bersifat permusuhan, penyalahgunaan atau penodaan terhadap suatu agama yang dianut di Indonesia.

a) Unsur pertama yaitu barang siapa yang menunjuk pada subjek hukum yang menjadi arah atau tujuan dari surat dakwaan atau subjek hukum yang didakwa telah melakukan suatu tindak pidana yang dalam hal ini termasuk terdakwa. Adapun surat dakwaan yang ditujukan pada perkara ini adalah Ir. Basuki Tjahaja Purnama alias Ahok.

b) Sebelum merujuk pada unsur kedua, maka akan disampaikan unsur yang ketiga terlebih dahulu. Unsur ketiga ialah di muka umum mengeluarkan perasaan atau melakukan perbuatan yang pada pokoknya bersifat permusuhan, penyalahgunaan atau penodaan agama adalah bersifat alternatif. Artinya bahwa salah satu frasa terpenuhi dalam perbuatan terdakwa maka cukup dan frasa lain tidak perlu dipertimbangkan.

c) Unsur kesengajaan, sengaja menurut $M v T$ ialah menghendaki dan mengetahui (willens en wetens). Menurut S.R. Sianturi dalam bukunya "Asas-Asas Hukum Pidana di Indonesia" mengartikan bahwa sengaja adalah dikehendaki dan diinsyafi (willens en wetens).

Berdasarkan pertimbangan hukum hakim di atas, penulis berpendapat bahwa hakim dalam kasus ini menggunakan interpretasi atau penafsiran multidisipliner. Interpretasi ini digunakan apabila dalam menangani suatu kasus, hakim harus mempertimbangkan masukan dari berbagai ilmu lain termasuk di luar ilmu hukum. Hal ini merujuk pada ahli-ahli yang dimintai keterangan yang digolongkan dalam tiga bidang.

\section{Kesimpulan}

1. Pembuktian unsur tindak pidana penodaan agama pada Putusan Nomor 1537/Pid.B/2016/PN.Jkt.Utr dibuktikan melalui alat bukti sebagaimana telah tercantum dalam Pasal 184 ayat (1) KUHAP. Pertama ialah keterangan saksi, pada hal ini berlaku asas unus testis 
nullus testis yang memiliki arti satu saksi bukan saksi. Namun hal tersebut telah terpenuhi dengan hadirnya dua puluh lima (25) orang saksi di persidangan. Kedua adalah keterangan ahli, pada pembuktian unsur tindak pidana penodaan agama lebih ditekankan pada alat bukti keterangan ahli. Hal tersebut merujuk pada ahli-ahli yang dihadirkan di persidangan. Ahliahli tersebut digolongkan menjadi tiga bidang yaitu ahli bahasa, ahli agama dan ahli hukum pidana. Ketiga adalah surat, adanya alat bukti surat pada kasus ini dikarenakan salah satu dari ahli tidak dapat memberikan keterangan di persidangan sehingga keterangan ahli di Berita Acara Pemeriksaan dibacakan kembali dan menjadi alat bukti surat. Keempat adalah keterangan terdakwa, bahwa terdakwa tidak merasa bersalah atas tindakan yang dilakukan serta tidak memiliki niat untuk melakukan penodaan agama.

2. Melalui alat-alat bukti yang terungkap selama persidangan, pertimbangan hukum hakim Putusan Nomor 1537/Pid.B/ 2016/PN.Jkt.Utr dalam amar amar putusannya menyatakan bahwa perbuatan terdakwa telah memenuhi unsur-unsur dalam Pasal 156a huruf a KUHP. Sehingga dapat disampaikan dalam hal ini hakim menggunakan interpretasi multidisipliner.

\section{Saran}

Berdasarkan hasil penelitian dan pembahasan penulis memberikan saran kepada tim penyusun Rancangan Undang-Undang Kitab Undang-Undang Hukum Pidana untuk memasukkan pengaturan kriteria khusus penodaan agama dalam ius constituendum.

\section{DAFTAR PUSTAKA}

Andi Hamzah, "Hukum Acara Pidana", Sinar Grafika, Jakarta, hlm. 145.

Eddy O.S. Hiariej, 2012, "Teori dan Hukum Pembuktian", Erlangga, Jakarta.

Hari Sasangka, 2007, "Penyidikan,

Penahanan, Penuntutan dan

Praperadilan dalam Teori dan Praktuk”, Mandar Maju, Bandung. Johny Ibrahim, 2007, "Teori dan

Metodologi Penelitian Hukum Normatif", Bayumedia Publishing, Malang.

Rusli Muhammad, 2006 "Potret Lembaga Pengadilan Indonesia”, Rajawali, Pers, Jakarta.

Ratna Nurul Afifah, 1998, "Barang Bukti dalam Proses Pidana", Sinar Grafika, Jakarta.

Sudarto, 1990, "Hukum Pidana I", Yayasan Sudarto Fakultas Hukum Universitas Diponegoro, Semarang. Suryono Sutarto, 1999, "Hukum Acara Pidana Jilid II", Badan Penerbit Fakultas Hukum Universitas Muria Kudus, Kudus.

\section{Peraturan Perundang-Undangan:}

Undang-Undang Dasar Negara

Republik Indonesia Tahun 1945. 
Undang-Undang Nomor 1 Tahun 1946 tentang Peraturan Hukum Pidana.

Undang-Undang Nomor 8 Tahun 1981 tentang Hukum Acara Pidana.

Undang-Undang Nomor 1/PNPS/ 1965 tentang Pencegahan Penyalahgunaan dan/atau Penodaan Agama.

Putusan Mahkamah Konstitusi Nomor 65/PUU-VII/2010.
Internet:

Estu Suryowati, "SETARA Institute: Kasus Penodaan Agama Menguat Pasca Reformasi”, http://nasional.kompas.com/read/20 17/05/24/16354351/setara.institute. kasus.penodaan.agama.menguat.pa sca.reformasi, diakses pada tanggal 2 Desember 2017 pukul 10.57 WIB. 